\title{
BENTUK KETERBUKAAN RAHASIA MEDIS DALAM SITUASI PANDEMI VIRUS COVID 19 DI INDONESIA
}

\author{
Afdhal \\ Irvansyah \\ Fakultas Hukum Universitas Borneo Tarakan \\ Email: afdhalmr1@gmail.com
}

\begin{abstract}
The right to confidentiality or privacy is something unique between a patient's relationship with a doctor because it is based on trust. This patient-doctor relationship is unique because the patient believes in the doctor's ability and the patient believes the doctor will keep the patient's secret. The influence of the covid 19 outbreak has made people nervous and afraid because the virus is very easy to spread and spreads globally. The community asks to open data related to the secrets of Covid 19 patients, both in the form of names, addresses, symptoms, diagnosis, and interactions that have been made. Patient data which is classified as a basic right to privacy is an important component in breaking the chain of the spread of Covid 19 because the government has implemented large-scale social restrictions in certain areas to maintain social interactions so that the community can avoid exposure to this virus. This needs to be studied in depth regarding the Forms of Disclosure of Medical Secrets in the PANDEMIC Covid 19 Situation in Indonesia.

This type of research is normative juridical research or what is known as doctrinal research. Normative juridical research is research that looks at problems through the aims and objectives to be achieved using surgical tools in the form of statutory regulations and regulations in a formal hierarchy of regulations as well as theoretical studies of updated and modern literature.

Covid 19 Patient Information is data stored in medical records that can be provided based on patient consent or the law. But in Article 57 paragraph (2) of Health Law, the right to confidentiality is excluded, one of which is for the benefit of society. The doctor's obligation to keep information related to the patient's medical condition is an obligation as described in the Republic of Indonesia Minister of Health Regulation Number 269 / MENKES / PER / III / 2008 concerning Medical Records but in the event of an outbreak or pandemic covid 19, the disclosure of secrets is carried out with the covid procedure, namely by evaluating the interaction of patients who have been in SWAB Positive and carry out self-isolation for COVID 19 patients without symptoms and medical isolation for patients with symptoms.
\end{abstract}

Keyword: Information, Covid 19, Hukum, Privacy

\section{PENDAHULUAN}

Manusia dan hukum adalah suatu kesatuan yang tidak dapat dipisahkan. manusia 
akan selalu menanyakan eksistensinya sebagai makhluk hidup di dunia ini, sebagaimana dijelaskan oleh Cicero yaitu dimana setiap masyarakat disitu ada hukum (Ibi societas Ibi lus) yang mana mengidentifikasikan bahwa setiap aktivitas masyarakat pasti ada hukumnya. Schuyt menjelaskan hukum merupakan sistem yang terdiri dari tiga komponen yang dimana tiga komponen yang dimaksud adalah keseluruhan peraturan hukum norma dan ketetapan yang dilukiskan sebagai sistem pengertian, keseluruhan organisasi dan lembaga yang mengemban fungsi dalam melakukan tugasnya dan keseluruhan ketetapan penanganan sosial Konkrit. ${ }^{23}$

Manusia di dalam mengupayakan kesehatannya sangat tergantung kepada keadaan lingkungan oleh karenanya manusia tidak hanya berorientasi kepada keadaan dirinya tetapi juga wajib untuk memelihara keadaan lingkungannya serta menghargai kesehatan manusia lainnya. Lingkungan yang menjadi faktor utama yaitu aspek wilayah atau tempat memiliki peran yang sangat penting. faktor sejarah telah membuktikan bahwa perkembangan kesehatan sangat ditentukan oleh lingkungan contoh pada abad ke-13 sampai ke-17 terjadi yang dinamakan sebagai endemik PES. Endemik ini terjadi di Cina dan India diperkirakan di India Mesir serta Gasa 13 ribu orang meninggal tiap harinya selama waktu tersebut jumlah kematian mencapai 60 juta orang, peristiwa tersebut dikenal dengan The Black Death. Peristiwa ini disebaabkan oleh lingkungan yang kotor dan menjadi tempat berkembang biaknya tikus sebagai sumber penyebaran virus.

Coronavirus atau covid 19 merupakan virus flu turunan dari virus Sars dengan tingkat penyebaran yang tergolong tinggi karena dapat ditularkan melalui droplet atau tetesan air tubuh manusia. Data Kementerian Kesehatan terkait dengan perkembangan kasus pneumonia wuhan 2019 menjelaskan pada tanggal 30 Desember 2019 pernyataan urgent not is on the treatment pneumonia of unknown cause. Pasien yang diidentifikasi adalah pasien yang ${ }^{24}$ mengalami gangguan pernafasan berat dimana

\footnotetext{
${ }^{23}$ Sabir Alwy and Afdhal Afdhal, "PERJANJIAN TERAPEUTIK SEBAGAI DASAR BAGI DOKTER D4ALAM MEAKUKAN PENANGANAN MEDIS," JURNAL AKTA YUDISIA, 2019.

World Heart Organition (WHO), "Tentang Novel Corona Virus", https://www.who.int/emergencies/diseases/novel-coronavirus-2019/situation-reports/
} 
suspek terus meningkat mencapai 59 orang dengan 7 kasus dalam kondisi berat semua dikarantina dan 163 tempat rapat di karantina. Who menyimpulkan bahwa virus ini adalah virus yang satu famili dengan virus a dan dipaparkan dalam virological.org oleh Universitas fudan Shanghai. pada tanggal 9 Januari 2020 WHO mengkonfirmasi buku novel Corona virus atau virus Corona yang baru telah berhasil diisolasi dari satu kasus yang dirawat di rumah sakit jumlah kasus konflik sebanyak 41 kasus dengan 1 kematian.

Pasien covid 19 atau Corona virus merupakan pasien yang memiliki gejala klinis baik itu ringan sampai pada gejala klinis yang tergolong berat serta membutuhkan penanganan medis yang dilakukan oleh seorang dokter. Corona virus merupakan virus yang bersumber dari suatu wilayah Wuhan di Negara Cina yang telah menjadi pandemic berdasarkan ketetapan World Health Organization (WHO).

Pasien yang memiliki hak atas pemeliharaan kesehatan the right to health care diatur oleh 4 faktor yaitu faktor sarana kesehatan yang memadai disesuaikan dengan keadaan klinis dari pasien, yang kedua adalah faktor geografis ini terkait dengan jenis penyakit yang sering ditemukan di wilayah tertentu, faktor finansial atau keuangan pasien yang tidak semuanya sama sehingga membutuhkan penanganan kesehatan secara adil di sarana kesehatan agar mendapatkan pelayanan yang berkualitas. Pasien memiliki hak untuk menentukan diri sendiri yang dibagi dua yaitu hak atas privasi dan hak atas badan sendiri. ${ }^{25}$

Hak atas privasi sebagaimana dijelaskan dalam kamus Black law dictionary to be alone yang di mana sifatnya tidak mutlak dipengaruhi oleh sistem didalam masyarakat serta dipengaruhi oleh posisi ataupun peran pasien tersebut di lingkungannya ${ }^{26}$. Hak atas rahasia ataupun privasi merupakan sesuatu yang unik hubungan pasien dengan dokter karena dilandaskan atas kepercayaan. Hubungan pasien dan dokter ini unik karena dianggap pasien percaya dengan kemampuan dokter dan pasien percaya dokter 25

Hermien Hadiati Koeswadji, "Hukum Kedokteran Di Dunia Internasional," in Medical Law (Jakarta, 1994), 3.

Alexander Hamilton Frey and Henry Campbell Black, "Black's Law Dictionary," University of Pennsylvania Law Review and American Law Register, 2006, https://doi.org/10.2307/3308065. 
akan menjaga rahasia pasien. Ruang lingkup rahasia kedokteran sebagaimana dijelaskan di dalam undang-undang nomor 29 tahun 2004 terkait dengan praktik kedokteran mendefinisikan rahasia kedokteran di dalam dua aspek yang pertama adalah segala sesuatu yang oleh pasien secara disdari atau tidak disdari disampaikan kepada dokter dan segala sesuatu yang oleh dokter telah diketahui waktu mengobati dan merawat pasien. Hak-hak mendasar terkait dengan kerahasiaan pasien yang wajib untuk dijaga oleh dokter merupakan suatu kewajiban yang diatur oleh undang-undang dan memiliki sanksi apabila tenaga kesehatan yaitu dokter melanggar aturan tersebut.

Data WHO terkait dengan pasien yang dinyatakan positif dikonfirmasi bertambah 3,76 juta jiwa dengan kategori sembuh 1,25 orang dan meninggal dunia sebanyak 264 Ribu orang di Indonesia sendiri sampai saat ini yang terkonfirmasi positif adalah 12.438 orang di mana pasien yang sembuh berjumlah 2.317 orang dan pasien yang meninggal berjumlah 895 orang. $^{27}$

Pengaruh wabah covid 19 membuat masyarakat menjadi gelisah dan ketakutan disebabkan oleh penyebaran virus yang sangat mudah dan menyebar secara global. Masyarakat meminta untuk membuka data terkait rahasia pasien covid 19 baik itu berupa nama, alamat, gejala, diagnosis, serta interaksi yang dilakukan. Data pasien yang tergolong sebagai hak dasar privacy menjadi komponen yang penting dalam memutus mata rantai penyebaran covid 19 dikarenakan pemerintah telah menerapkan pembatasan social berskala besar di daerah tertentu untuk menjaga interaksi sosial agar masyarakat dapat terhindar dari paparan virus ini. Hal ini yang perlu dikaji secara mendalam terkait Bentuk Keterbukaan Rahasia Medis Dalam Situasi Pendemic Virus Covid 19 Di Indonesia.

\section{A. Rumusan Masalah}

Berdasarkan latar belakang diatas, maka rumusan permasalahan dalam usulan penelitian ini adalah:

\footnotetext{
${ }^{27}$ World Heart Organition (WHO), "Tentang Novel Corona Virus", https://www.who.int/emergencies/diseases/novel-coronavirus-2019/situation-reports/
} 
1. Bagaimanakah Mekanisme Berdasarkan Hukum Formil Membuka Data Rahasia Medis Pasien Covid 19 di Indonesia?

2. Bagaimanakah bentuk informasi Rahasia Medis pasien covid 19 yang diberikan kepada masyarakat umum di Indonesia agar tidak melanggar ketentuan perundang-undangan?
A. Tujuan Penelitian

Berkenaan dengan rumusan masalah diatas, penelitian dosen pemula ini bertujuan untuk:

1. Mengetahui cara membuka data rahasia medis pasien Covid 19 di Indonesia.

2. mengetahui bentuk informasi Rahasia Medis pasien covid 19 yang dapat diberikan kepada masyarakat umum di Indonesia agar tidak melanggar ketentuan perundang-undangan.

D. Manfaat Penelitian

1. Penelitian ini diharapkan dapat memberikan pengetahuan bagi pihak-pihak yang terdampak oleh virus covid 19 agar dapat secara efektif menghindari lingkungan yang dikategorikan berbahaya

2. Penelitian ini diharapkan mampu menjadi solusi dalam memutus mata rantai penyebaran covid 19

\section{TINJAUAN PUSTAKA}

\section{A. Hubungan Dokter dan Pasien}

Dokter, merupakan salah satu tenaga medis yang dapat diambil sebagai pihak yang melakukan atau melaksanakan pelayanan kesehatan. Pengertian dokter dapat dillihat pada ketentuan Pasal 1 angka 2 Undang-Undang Nomor 29 Tahun 2004 tentang 
Praktek Kedokteran, yaitu:

“ Dokter dan Dokter gigi adalah dokter, dokter spesialis, dokter gigi, dan dan dokter gigi spesialis lulusan pendidikan kedokteran atau kedokteran gigi baik di dalam maupun diluar negeri yang diakui oleh Pemerintah Republik Indonesia sesuai denga peraturan perundang-undangan". ${ }^{28}$

Dari penjelasan diatas maka dokter merupakan sebagai pengemban profesi yang mengabdikan diri dalam bidang kesehatan serta memiliki pengetahuan dan keterampilan melalui pendidikan dibidang kesehatan yang melakukan upaya kesehatan

Soerjono Soekanto mengemukakan bahwa Pasien adalah orang sakit yang dirawat oleh dokter dan tenaga kesehatan lainnya ditempat praktek atau rumah sakit ${ }^{29}$. Pasien adalah orang yang menjadi sasaran dalam usaha-usaha penyembuhan yang dilakukan oleh dokter atau tenaga kesehatan lainya. Sebagai subjek hukum pasien mempunyai hak dan kewajiban yang harus dipahami baik oleh pasien, dokter maupun rumah sakit sebagai salah satu tempat diselenggarakanya profesi kedokteran demi tercapainya tujuan upaya kesehatan sesuai dengan ketentuan Undang-UndangNo. 44 Tahun 2009 Pasal 1 angka 1 Tentang Rumah Sakit yaitu:

“Pasien adalah setiap orang yang melakukan konsultasi masalah kesehatannya untuk memperoleh pelayanan kesehatan yang diperlukan baik secara lansungmaupun tidak lansung di rumah sakit". 30

\section{B. Rumah Sakit}

Rumah Sakit, dapat diartikan sebagai sarana pelayanan kesehatan. Selain itu , rumah sakit juga dapat merupakan suatu tempat bagi tenaga medis berkumpul atau

\footnotetext{
${ }^{28}$ Presiden Republik Indonesia, “Undang Undang Republik Indonesia Nomor 29 Tahun 2004 Tentang Praktik Kedoteran," Undang Undang Praktik Kedokteran, 2004, https://doi.org/10.1017/CB09781107415324.004.

Soerjono Soekanto, "Hak Dan Kewajiban Pasien Menurut Hukum Kesehatan," Jurnal Hukum \& Pombangunan, 1990, https://doi.org/10.21143/jhp.vol20.no2.884.

Republik Indonesia, "UU RI Momor 44 Tahun 2009 Tentang Rumah Sakit," Jakarta, 2009, https://doi.org/10.1017/CB09781107415324.004.
} 
lokasi dimana berbagai tenaga ahli atau padat karya dan juga merupakan lembaga padat moral, padat teknologi dan padat waktu. Rumah sakit merupakan pusat pelayanan medis atau juga pelayanan kesehatan, sebagaimana sesuai dengan UndangUndang Rumah Sakit No. 44 tahun 2009 Pasal 1 angka 1 yaitu:

"Rumah Sakit adalah institusi pelayanan kesehatan yang menyelenggarakan pelayanan kesehatan perorangan secara paripurna yang menyediakan pelayanan rawat inap, rawat jalan,dangawat darurat". Rumah sakit merupakan pusat pelayanan medis atau juga pelayanan kesehatan, sebagaimana menurut A. Azwar untuk terselanggaranya pelayanan medis yang baik, banyak syarat yang harus dipenuhi, mencakup 8 (delapan) hal pokok yaitu tersedia (available), wajar (appropriate), berkesinambungan (continue), dapat diterima (acceptable), dapat dicapai (accesible), dapat dijangkau (affordable), efisien (effecient), dan bermutu (quality). Pelayanan kesehatan merupakan salah satu. upaya yang dapat dilakukan untuk meningkatkan derajat kesehatan baik perseorangan, maupun kelompok atatu masyarakat secara keseluruhan. Pelayanan medis merupakan suatu bentuk upaya, yang diberikan oleh tenaga medis dokter/dokter gigi ${ }^{31}$ dan perawat sesuai yang diatur dalam Pasal 1 angka 1 Undang-undang Kesehatan No. 36 Tahun 2009 yaitu $:^{32}$

"Upaya Kesehatan adalah setiap kegiatan dan atauu serangkaian kegiatan yang dilakukan secara terpadu, terintegrasi dan berkesinambungan untuk memelihara dan meningkatkan derajat kesehatan masyarakat dalam bentuk pencegahan penyakit, peningkatan kesehatan, pengobatan penyakit, dan pemulihan kesehatan oleh pemerintah dan atau masyarakat"

\section{Rekam Medis}

Rekam medis merupakan catatan/tulisan-tulisan yang dibuat oleh dokter atau dokter gigi mengenai tindakan-tindakan yang dilakukan kepada pasien dalam rangka pelayanan kesehatan. Sedangkan dokumen adalah catatan dokter, dokter gigi, dan / atau tenaga kesehatan tertentu, laporan hasil pemeriksaan penunjang, catatan observasi dan pengobatan harian dan semua rekaman, baik berupa foto radiologi, gambar pencitraan (imaging), dan rekaman elektro diagnostik. Penjelasan tersebut

31

azwar Azrul, Pengantar Administrasi Kesehatan, Edisi Ke Enam., Bina Rupa Aksara; Jakarta, 2010, https://doi.org/10.1378/chest.07-1909.

Presiden RI, UU RI No 36 Tentang Kesehatan, UU RI No 36 2009, issued 2009. 
sesuai dengan Permenkes No. 269 Tahun 2008 Pasal 1

Ayat(1), (6), dan (7)tentang Rekam Medis yang mengatur bahwa:

1) "Rekam Medis adalah berkas yang berisikan catan dan dokumen tentang identitas pasien, pemeriksaan, pengobatan, tindakan dan pelayanan lainyang telah diberikan kepada pasien."

6) Catatan adalah tulisan yang dibuat oleh dokter atau dokter gigi tentang segala tindakan yang dilakukan kepada pasien dalam rangka pemberian pelayanan kesehatan 7)

7) Dokumen adalah catatan dokter, dokter gigi, dan/atau tenaga kesehatan tertentu, laporan hasil pemeriksaanpenunjang, catan observasi dan pengobatan harian dan semua rekaman baik, baik berupa foto radiologi, gambar pencitraan (imaging), dan rekaman elektro diagnostik.

Rekam medis harus dibuat secara tertulis, lengkap dan jelas serta dalam bentuk informasi elektronik. Rekam medis terdiri dari catatan-catatan yang dianggap penting dan berhubungan langsung dengan data serta informasi yang dibutuhkan oleh dokter atau dokter gigi dalam menentukan keputusan baik berupa pengobatan, penanganan, ataupun tindakan medis lainnya. Pembuatan rekam medis dilaksanakan melalui pencatatan dan pedokumentasian hasil pemeriksaan, pengobatan, tindakan, dan pelayanan lain yang telah diberikan kepada pasien. Setiap pencatatan pada rekam medis harus dibubuhi nama, waktu dantanda tangan dokter, dokter gigi atau tenaga kesehatan tertentu yang memberikan pelayanan kesehatan secara langsung.

Bila terjadi kesalahan dalam melakukan pencatan dalam rekam medis dapat dilakukan pembetulan dengan cara pencoretan tanpa menghilangkan catatan yang dibetulkan dan dibubuhi paraf dokter, dokter gigi atau tenaga kesehatan tertentu yang bersangkutan ini sesuai dengan Permenkes No 269 Tahun 2008 Pasal 5 ayat 5 dan

Kerahasiaan Medik Dalam Praktik Kedokteran 
Rahasia medic merupakan bagian dari hak dasar kesehatan seorang individu yaitu ha katas privacy. Setiap tenaga kesehatan wajib untuk merahasiakan tindakan medis yang dilakukan kepada seorang pasien.

Pasal 48 Undang-Undang Praktik Kedokteran Menjelaskan:

1) Setiap dokter atau dokter gigi dalam melaksanakan praktik kedokteran wajib menyimpan rahasia kedokteran

2) Rahasia kedokteran dapat dibuka hanya untuk kepentingan kesehatan pasien, memenuhi permintaan aparatur penegak hukum dalam rangka penegakan hukum, permintaan pasien sendiri, atau berdasarkan ketentuan perundangundangan

3) Ketentuan lebih lanjut mengenai rahasia kedokteran diatur dengan peraturan menteri

Pasal 57 Undang-Undang Kesehatan Nomor 36 Tahun 2009 menjelaskan

Setiap orang berhak atas rahasia kondisi kesehatan pribadinya yang telah dikemukakan kepada penyelenggaraan pelayanan kesehatan Ketentuan mengenai hak atas rahasia kondisi kesehatan pribadi, tidak berlaku dalam hal:

(a) Perintah UU

(b) Perintah pengadilan

(c) Izin yang bersangkutan

(d) Kepentingan masyarakat

(e) Kepintangan orang tersebut

Rahasia kedokteran adalah Sesuatu yang berhubungan dengan hal yang ditemukan oleh dokter dan dokter gigi dalam rangka pengobatan dan dicatat dalam Rekam Medis yang dimiliki pasien bersifat rahasia ( Penjelasan Pasal 38 (1) Undang-U ndang Rumah Sakit)

\section{PEMBAHASAN}

Hak dasar manusia sebagai mahluk hidup ciptaan Allah SWT yang dibagi dalam 2 
hak dasar kesehatan yaitu Hak dasar sosial dan hak dasar individu merupakan hak yang melekat sejak kita dilahirkan. Konstitusi sebagai aturan dasar kenegaraan menjamin hak setiap warga Negara untuk mendapatkan hak atas pemeliharaan kesehatan. Hak pemeliharaan kesehatan (the right to health care) sangat penting bagi setiap individu guna mewujudkan kehidupan yang produktif oleh karenanya ada beberapa factor yang mempengaruhinya yaitu
a. Faktor Sarana Kesehatan
b. Faktor Geografis
c. Faktor Finansial/keuangan
d. Faktor Kualitas

Hak dasar manusia tidak dapat ditentukan oleh aturan yang dibuat pemerintah karena hak tersebut merupakan kodrat humanis yang dimiliki setiap orang semenjak dia dilahirkan. Hak untuk menentukan diri sendiri/nasib sendiri (the right of self determination) merupakan hak yang dibagi atas hak atas privacy dan hak atas badan sendiri. Hak atas privacy sebagai kemampuan suatu individu untuk mengontrol informasi mengenai diri pribadi dengan tujuan melindungi kehidupan dan urusan personalnya merupakan suatu upaya yang dilakukan untuk mengamankan diri dari pengaruh publik. Hak pelanggaran terhadap privasi menjadi hal yang sangat penting karena dapat mengakibatkan kesalahan interpretasi terhadap suatu informasi yang pada akhirnya menjadi masalah hukum. Negara sebagai organisasi tertinggi yang mengatur hak setiap warga negaranya wajib untuk mengatur hak privasi setiap warga Negara agar tidak menganggu informasi publik yang diterima masyarakat.

Kamus Black's Law mengartikan hak atas privacy sebagai to be let alone artinya sebagai individu zoon politicon manusia juga memiliki hak untuk mengurus kepentingan pribadinya. Hat atas privacy sifatnya tidak mutlak karena dipengaruhi oleh sitem yang ada di masyarakat yaitu system pemerintahan yang menjadi mesin penggerak segala kebijakan dalam bernegara. Budaya pada masyarakat juga menjadi aspek yang 
mempengaruhi seorang individu dalam mengamankan dirinya di masyarakat contoh bagi Negara barat hamil tanpa hubungan pernikahan merupakan hal yang wajar tetapi bagi kita masyarakat yang hidup dan tinggal di Indonesia merupakan hal yang terlarang serta membuat setimen negatif di masyarakat.

Pasien yang datang ke dokter dengan tujuan untuk konsultasi masalah kesehatanya memiliki hubungan yang unik karena yang menjadi tujuan dokter bukan menyembuhkan tetapi upaya yang dilakukan oleh seorang dokter berdasarkan kompetensinya. Inspaningverbitenis merupakan bentuk prestasi yang tujuanya bukan pada hasil resultatverbitenis tetapi pada proses yang telah diatur berdasarkan standar profesi, standar pelayanan, dan standar prosedur operasional.

Proses pelayanan kesehata berdasarkan standar profesi sangat ditentukan oleh kompetensi seorang dokter serta informasi yang diberikan oleh pasien. Informasi yang diberikan oleh pasien adalah segala sesuatu yang secara sadar atau tidak sadar disampaikan kepada dokter. Informasi yang bersumber dari segala sesuatu yang oleh dokter diketahui ketika melakukan diagnosis dan merawat pasien ini di susun dan dicatat dalam rekam medis pasien.

Pada pasal 28 H ayat (1) Undang-Undang Dasar Negara Republik Indonesia Tahun 1945 ditegaskan bahwa setiap orang berhak memperoleh pelayanan kesehatan, kemudian dalam pasal 34 ayat (3) dinyatakan Negara bertanggung jawab atas penyediaan fasilitas pelayanan kesehatan dan fasilitas pelayanan umum yang layak. Sehubungan dengan penyelenggaraan, maka peranan fungsi hukum sebagai social engineering pada terjadinya perkembangan ilmu.

Pada Bidang kesehatan perubahan tata nilai dan pemikiran masyarakat serta tingkat pendidikan masyarakat, yang mendorong tuntutan masyarakat akan adanya pelayanan kesehatan yang bermutu dan adanya kepastian hukum baik pemberi pelayanan kesehatan (health provider)maupun penerima kesehatan (health receiver).

Undang-undang No. 44 Tahun 2009 tentang Rumah Sakit dibentuk dalam rangka memberikan kepastian dan perlindungan hukum untuk meningkatkan, mengarahkan, 
dan memberikan dasar bagi pengelolaan rumah sakit secara menyeluruh. Dalam pasal 3 disebutkan penyelenggaan rumah sakit bertujuan untuk mempermudah akses masyarakat untuk mendapatkan pelayanan sehatan dan memberikan perlindungan terhadap keselamatan pasien, masyarakata, lingkungan rumah sakit dasn sumber daya manusia di rumah sakit.

Pada pasal 2 penjelasan Undang-Undang No. 36 Tahun 2009 tentang kesehatan dinyatakan bahwa pembangunan kesehatan harus memperhatikan berbagai asas yang memberikan arah pembangunan kesehatan. Asas yang keempat dari pasal tersebut adalah asas perlindungan berarti bahwa pembangunan kesehatan harus dapat memberikan perlindungan dan kepastian hukum kepada pemberi dan penerima pelayanan kesehatan. Asas tersebut dilaksanakan melalui upaya kesehatan.

Undang-Undang No. 44 Tahun 2009 tentang Rumah Sakit pasal 19, rumah sakit dapat dibagi berdasarkan jenis pelayanan yang diberikan, rumah sakit yang dikategorikan rumah sakit umum dan rumah sakit khusus. Rumah sakit umum yaitu rumah sakit yang memberikan pelayanan kesehatan pada semua jenis bidang dan jenis penyakit. Rumah sakit Khusus yaitu rumah sakit yang memebrikan pelayanan utama pada satu bidang dan jenis penyakit teretentu berdasarkan disiplin ilmu, golongan umur, organ, jenis penyakit atau kekhususan lainnya.

Peran dan fungsi rumah sakit sebagai tempat untuk melakukan pelayanan medis yang proporsional akan erat kaitannya dengan 3 (tiga) unsur, yaitu terdiri dari : (1) unsur mutu yang dijamin kualitasnya, (2) Unsur keuntungan atau manfaat yang tercermin dalam mutu pelayanan, (3) Hukum yang mengatur perumahsakitan secara umum dan kedokteran/atau medik khususnya.

Menurut Waters dan Murphy : Kompendium (Ikhtisar) yang berisi informasi tentang keadaan pasien selama perawatan atau selama pemeliharaan kesehatan. Menurut Edna K Huffman : Rekam medis adalah berkas yang menyatakan siapa, apa, mengapa, dimana, kapan dan bagaimana pelayanan yang diperoleh seorang pasien selama dirawat atau menjalani pengobatan. 
Dalam Undang-Undang Praktik Kedokteran Republik Indonesia No. 29 Tahun 2004, Pasal 46:

1. Setiap dokter atau dokter gigi dalam menjalankan praktik kedokteran wajib membuat rekam medis,

2. Rekam medis sebagaimana dimaksud pada ayat (1) harus segera dilengkapi setelah pasien selesai menerima pelayanan kesehatan,

3. Setiap catatan rekam medis harus dibubuhi nama, waktu, dan tanda tangan petugas yang memberikan pelayanan atau tindakan.

Pasal 47 menyatakan bahwa :

1. rekam medis sebagaimana dimaksud dalam pasal 46 merupakan milik dokter, dokter gigi, atau sarana pelayanan kesehatan sedangkan isi rekam medis merupakan milik pasien

2. Rekam medis sebagaimana dimaksud pada ayat (1) harus disimpan dan dijaga kerahasiaannya oleh dokter atau dokter gigi dan pimpinan sarana pelayanan kesehatan,

3. Ketentuan mengenai rekam medis sebagaimana dimaksud pada ayat (1) dan (2) diatur dengan Peraturan Menteri.

Peraturan Memteri Kesehatan No : 269/MENKES/PER/III/2008 tentang Rekam Medis Pasal 1 ayat (1) menyatakan bahwa rekam medis adalah berkas yang berisi catatan dan dokumen tentang identitas pasien, pemeriksaan, pengobatan, tindakan dan pelayanan lain yang telah diberikan kepada pasien. Pasal 1 angka 7 Permenkes No 269/MENKES/PER/III/2008 tentang Rekam Medis menyatakan dokumen adalah catatan dokter, dokter gigidan /atau tenaga kesehatan tertentu, laporan hasil pemeriksaan penunjang, catatan observasi dan pengobatan harian dan semua rekaman, baik berupa foto radiologi, gambar pencitraan (imaging) dan rekaman elektro diagnostic.

Rekam medis terdiri dari catatan-catatan data pasien yang dilakukan dalam pelayanan kesehatan. Catatan-catatan tersebut sangat penting untuk pelayanan bagi pasien kerana dengan data yang lengkap dapat memberikan informasi dalam menentukan keputusan baik pengobatan, penanganan, tindakan medis dan lainnya. Dokter atau dokter gigi diwajibkan membuat rekam medis sesuai aturan yang berlaku. Menurut Peraturan Menteri Kesehatan Republik Indonesia Nomor 269/MENKES/PER/III/2008 tentang Rekam Medis, isi rekam medis dibedakan menurut pasiennya, yaitu : 
1. Isi rekam medis untuk pasien rawat jalan pada sarana pelayanan kesehatan sekurang-kurangnya memuat :

2. Identitas Pasien

3. Tanggal dan waktu

4. Hasil anamnesisi, mencakup sekurang-kurangnya keluhan dan riwayat penyakit

5. Hasil pemeriksaan fisik dan penunjang medic

6. Dignosis

7. Rencana penatalaksanaan

8. Pengobatan dan/atau tindakan

9. Pelayanan lain yang telah diberikan kepada pasien

10. Untuk pasien kasus gigi dilengkapi dengam odontogram klinik

11. Persetujuan tindakan bila diperlukan

Isi rekam medis untuk pasien rawat inap dan perawatan satu hari sekurang-kurangnya memuat :

1. Identitas pasien

2. Tanggal dan waktu

3. Hasil anamnesis, mencakup sekurang-kurangnya keluahan dan riwayat penyakit

4. Hasil pemeriksaan fisik dan penunjang medic

5. Diagnosis

6. Rencana penatalaksanaan

7. Pengobatan dan/atau tindakan

8. Persetujuan tindakan bila perlu

9. Catatan observasi klinis dan hasil pengobatan

10. Ringkasan pulang (discharge summary)

11. Nama dan tanda tangan dokter, dokter gigi atau tenaga kesehatan tertentu yang memberikan pelayanan kesehatan 
12. Pelayanan lain yang dilakukanoleh tenaga kesehatan tertentu, dan

13. Untuk pasien kasus gigi dilengkapi dengan odontogram klinik

Isi rekam medis untuk pasien gawat darurat, sekurang-kurangnya memuat :

1. Identitas pasien

2. Kondisi saat pasien tiba di sarana pelayanan kesehatan

3. Identitas pengantar pasien

4. Tanggal dan waktu

5. Hasil amnesis, mencakup sekurang-kurangnya keluhan dan riwayat penyakit

6. Hasil pemeriksaan fisik dan penunjang medic

7. Diagnosis

8. Penjgobatan dan/atau tindakan

9. Ringkasan kondisi pasien sebelum meninggalkan pelayanan unit gawat darurat dan rencana tindak lanjut

10. Nama dan tanda tangan dokter, dokter gigi, atau tenaga kesehatan tertentu yang memberikan pelayanan kesehatan

11. Sarana transportasi yang digunakan bagi pasien yang akan dipindahkan ke sarana kesehatan lainnya, dan

12. Pelayanan lain yang telah diberikan kepada pasien

13. Isi rekam medis pasien dalam keadaan bencana sama dengan isi rekam medis pada no. 3, namun terdapat tambahan, yakni :

a. Jenis bencana dan lokasi dimana pasien ditemuka

b. Kategori kegawatan dan nomor pasien bencana massal, dan

c. Identitas yang menemukan pasien :

Menurut Peraturan Menteri Kesehatan Republik Indonesia Nomor 269/MENKES/PER/III/2008 tentang Rekam Medis adalah :

Dokter, dokter gigi dan/atau tenaga kesehatan tertentu bertanggung jawab atas catatan dan/atau dokumen yang dibuat pada rekam medis 
Penyimpanan dan pemusnahan

a. Rekam medis pasien rawat inap di rumah sakit wajib disimpan sekurangkurangnya untuk jangka waktu 5 Menurut Peraturan Menteri Kesehatan Republik Indonesia Nomor 269/MENKES/PER/III/2008 tentang Rekam Medis, isi rekam medis dibedakan menurut pasiennya, yaitu 5 (lima) tahun terhitung dari tanggal terakhir pasien berobat atau dipulangkan

b. Detelah batas waktu 5 (lima) tahun dilampaui, rekam medis dapat dimusnahkan kecuali ringkasan pulang dan persetujuan tindakan medic

c. Ringkasan pulang dan persetujuan tindakan medic harus disimpan untuk jangka waktu 10 (sepuluh) tahun terhitung dari tanggal dibuatnya ringkasan tersebut

d. Penyimpanan rekam medic dan ringkasan dilaksanakan oleh petugas yang ditunjuk oleh pimpinan sarana pelayanan kesehatan

e. Rekam medis pada sarana pelayanan kesehatan non rumah sakit wajib disimpan sekurang-kurangnya 2 (dua) tahun terhitung dari tanggal terakhir pasien berobat

f. Setalah batas waktu, rekam medis dapat dimusnahkan

g. Kerahasiaan

Informasi tentang identitas, diagnosis, riwayat penyakit, riwayat pemeriksaan dan riwayat pengobatan pasien harus dijaga kerahasiaannya oleh dokter, dokter gigi, tenaga kesehatan tertentu, petugas pengelola dan pimpinan sarana pelayanan kesehatanInformasi tentang identitas, diagnosis, riwayat penyakit, riwayat pemeriksaan dan riwayat pengobatan dapat dibuka dalam hal :

1. Untuk kepentingan kesehatan pasien

2. Memenuhi permintaan aparatur penegak hukum dalam rangka penegakan hukum atas perintah pengadilan

3. Permintaan dan/atau perseyujuan pasien sendiri

4. Permintaan institusi/lembaga berdasasarkan ketentuan perundang-undagan

5. Untuk kepentingan penelitian, pendidikan, dan audit medis, sepanjang tidak menyebutkan identitas pasien. Dengan syarat harus dilakukan secara tertulis kepada pimpinan sarana pelayanan kesehatan 
Penjelasan tentang isi rekam medis hanya boleh dilakukan oleh dokter atau dokter gigi yang merawat pasien dengan izin tertulis pasien atau berdasarkan peraturan perundang-undangan. Pimpinan sarana pelayanan kesehatan dapat menjelaskan isi rekam medis secara tertulis atau langsung kepada pemohon tanpa izin pasien berdasarkan peraturan perundang-undangan. Hak pasien dalam informasi tentang rekam medis berdasarkan Permenkes RI Nomor 269/MENKES/PER/III/2008 tentang Rekam Medis pasal 12 dikatakan bahwa berkas rekam medis dalah milik sarana pelayanan kesehatan da nisi rekam medis adalah milik pasien. Bentuk ringkasan rekam medis dapat diberikan, dicatat, atau dicopy oleh pasien atau orang yang diberi kuasa atau persetujuan tertulis pasien atau keluarga pasien yang berhak untuk itu. Namun boleh tidaknya pasien mengetahui isi rekam medis tergantung kesanggupan pasien untuk mendengar informasi mengenai penyakit yang dijelaskan oleh dokter yang merawatnya. Pada sisi hukum bahwa tuntutan-tuntutan dapat saja terjadi bila dirasakan bagi pasien sebagai penerima pelayanan kesehatan tidak puas atau ada dugaan-dugaan dokter melakukan praktik kedokteran tidak benar atau melanggar standar sehingga pasien dirugikan. Tuntutan-tuntutan tersebut dapat berupa :

1. Diatur dalam pasal 1365 Kitap Undang-Undang Hukum Perdata yaitu setiap perbuatan melanggar hukum yang membawa kerugian kepada orang lain, mewajibkan orang yang karena kesalahannya menerbitkan kerugian atau menggantinya

2. Diatur dalam pasal 1366 Kitap Undang-Undang Hukum Perdata yaitu setiap orang bertanggung jawab tidak saja untuk kerugian yang disebabkan karena perbuatannya, tapi juga untuk kerugian yang disebabkan karena kelalaian atau kurang hati-hati

3. Diatur dalam pasal 1367 Undang-Undang Hukum Perdata yaitu bertanggung jawab atas kerugian tidak saja karena perbuatannya sendiri tetapi juga kerugian yang timbul atas perbauatan orang-orang yang menjadi tanggungan yaitu orang yang ada di bawah pengawasannya. 
Peneliti juga melakukan pengamatan melalui form google yang dibagi kepada masyarakat yang terdampak covid 19 dan didaptkan 39 responden dengan hasil:

1. Dari 39 responden maka 20 responden memberikan keterangan bahwa memiliki hubungan langsung dengan pasien covid 19 sisanga yaitu 19 orang tidak

2. Dari 39 responden 29 responden menyatakan betapa pentingnya informasi lokasi pasien covid agar masyarakat dapat menghindari lokasi tersebut.

3. Penyebaran informasi covid 19 dapat di dapatkan pada social media ini dinyatakan oleh 21 responden dan 7 responden menyatakan mendapatkanya melalui berita

4. Dari 39 responden maka 29 responden menyatakan informasi terkait nama, lokasi dan interaksi pasien perlu dilakukan keterbukaan agar masyarakat dapat terhindar dari penyebaran covid 19 yang massal

5. Bagi masyarakat yang tinggal pada lokasi zona merah penyebaran covid maka 6 responden memilih untuk tinggal dirumah dan menunggu informasi lengkap terkait turunya intensitas penyebaran covid 19

Informasi Pasien Covid 19 merupakan data di simpan dalam rekam medis yang dapat diberikan berdasarkan persetujuan pasien atau undang-undang. Tetapi pada UndangUndang Kesehatan Pasal 57 ayat (2), hak atas kerahasiaan itu dikecualikan salah satunya demi kepentingan masyarakat.

Kesimpulan:

Kewajiban Dokter dalam merahasiakan keterangan terkait keaadaan medis pasien merupakan kewajiban sebagaimana dijelaskan dalam Permenkes RI Nomor 269/MENKES/PER/III/2008 tentang Rekam Medis tetapi dalam hal terjadinya suatu wabah atau pandemic covid 19 maka pembukaan rahasia tersebut dilakukan dengan prosedur covid yaitu dengan mengevaluasi interaksi pasien yang telah di SWAB Positif 
dan melakukan isolasi mandiri bagi pasien covid 19 tanpa gejala dan isolasi medis bagi pasien dengan gejala.

\section{Daftar Pustaka}

Alwy, Sabir, and Afdhal Afdhal. "PERJANJIAN TERAPEUTIK SEBAGAI DASAR BAGI DOKTER DALAM MEAKUKAN PENANGANAN MEDIS." JURNAL AKTA YUDISIA, 2019.

Azrul, azwar. Pengantar Administrasi Kesehatan, Edisi Ke Enam. Bina Rupa Aksara; Jakarta, 2010. https://doi.org/10.1378/chest.07-1909.

Frey, Alexander Hamilton, and Henry Campbell Black. "Black's Law Dictionary." University of Pennsylvania Law Review and American Law Register, 2006. https://doi.org/10.2307/3308065.

Koeswadji, Hermien Hadiati. "Hukum Kedokteran Di Dunia Internasional." In Medical Law, 3. Jakarta, 1994.

Presiden Republik Indonesia. “Undang Undang Republik Indonesia Nomor 29 Tahun 2004 Tentang Praktik Kedoteran." Undang Undang Praktik Kedokteran, 2004. https://doi.org/10.1017/CB09781107415324.004.

Presiden RI. UU RI No 36 Tentang Kesehatan. UU RI No 36 2009, issued 2009.

Republik Indonesia. “UU RI Momor 44 Tahun 2009 Tentang Rumah Sakit.” Jakarta, 2009. https://doi.org/10.1017/CB09781107415324.004.

Soekanto, Soerjono. "Hak Dan Kewajiban Pasien Menurut Hukum Kesehatan.” Jurnal Hukum \& Pembangunan, 1990. https://doi.org/10.21143/jhp.vol20.no2.884. 